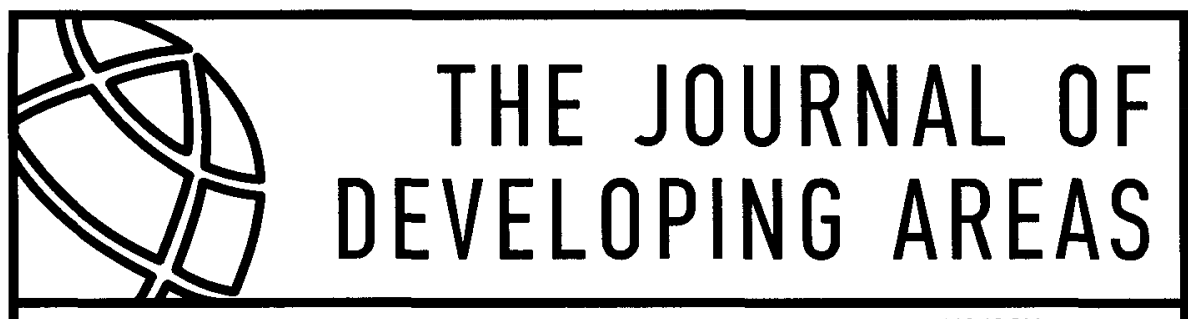

US ISSN 0022-037X

JDA's purpose is to stimulate descriptive, theoretical, and comparative study of regional development, and promote a fuller understanding of the human relationship to the development process. Issues consist of four to six articles, book reviews, and occasional guest editorials.

WILLIAM C. THIESENHUSEN

JONAS PRAGER

W. E. HEWITT

GREGORY D. SCHMIDT

DALE B. TRUETT and LILA J. TRUETT

DEBORAH BRAUTIGAM

HOLLYY SIMS

DON P. CLARK

RONALD V. A. SPROUT and JAMES H. WEAVER

RICHARD HAEUBER
Implications of the Rural Land Tenure System for the Environmental Debate: Three Scenarios

Is Privatization a Panacea for LDCs? Market Failure versus Public Sector Failure

The Roman Catholic Church and Environmental Politics in Brazil

Beyond the Conventional Wisdom: USAID Projects, Interorganizational Linkages, and Institutional Reform in Peru

Nonprimary Exports of African LDCs: Have Trade Preferences Helped?

Land Rights and Agricultural Development in West Africa: A Case Study of Two Chinese Projects

Economic Imperatives, Political Risks, and Modes of Action: Agricultural Policy Implementations in India and Pakistan

Nontariff Measures and Developing Country Exports

Exports and Economic Growth in a Simultaneous Equations Model

Development and Deforestation: Indian Forestry in Perspective

Issued October, January, April, July

North America (personal)--\$25.00, North America

(institutional)- $\$ 35.00$, Elsewhere--\$35.00

THE JOURNAL OF DEVELOPING AREAS

Western Illinois University

Macomb, Illinois 61455 


\section{WORLD HEALTH AND WORLD POLITICS}

The World Health Organization and the UN System by Javed Siddiqi

A report card for one of the United Nations' most important agencies.

"Siddiqi has shown that world health and world politics are indeed inseparable. At the same time, he has rightly separated charges of politicization from alleged ineffectiveness." Yves Beigbeder, author of Management Problems in United Nations Organizations

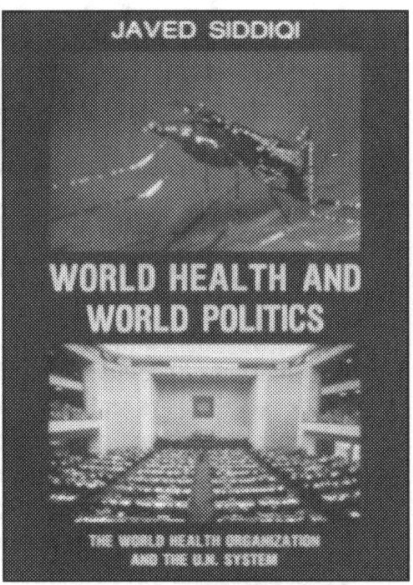

\section{UNIVERSITY OF SOUTH CAROLINA PRESS} 205 Pickens Street • Columbia, SC 29208

Toll-free orders: 1-800-768-2500 - Toll-free fax: 1-800-868-0740

$\$ 4.00$ shipping \& handling for the first book, .50 each additional book

\section{This publication is} available in microform.

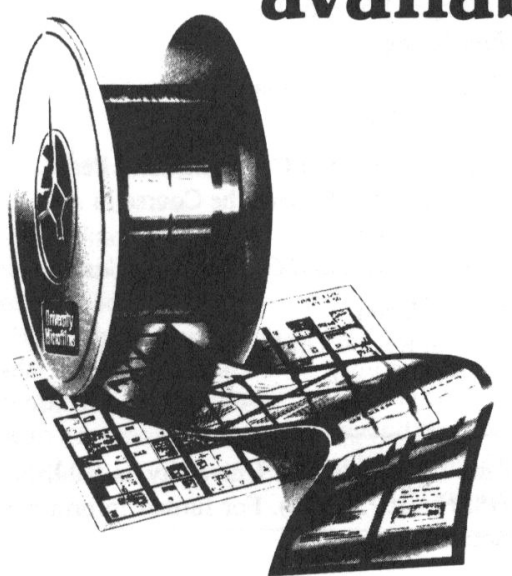

University Microfilms International
University Microfilms International reproduces this publication in microform: microfiche and $16 \mathrm{~mm}$ or $35 \mathrm{~mm}$ film. For information about this publication or any of the more than 13,000 titles we offer, complete and mail the coupon to: University Microfilms International, 300 N. Zeeb Road, Ann Arbor, MI 48106. Call us toll-free for an immediate response: 800-521-3044. Or call collect in Michigan. Alaska and Hawaii: 313-761-4700.

$\square$ Please send information about these titles:

Name

Company/Institution

Address

City Zip

Phone ( ) 


\section{G L O B A L GOVERNANCE}

\section{A Review of Multilateralism and International Organizations}

Launched in February 1995, Global Governance provides a much-needed forum for practitioners and academics to discuss the impact of international institutions and multilateral processes on: economic development; human rights; peace and security; and the preservation of the environment.

The editors and editorial board are committed to ensuring that the journal has a truly global focus, and contributions will be published from a wide range of multidisciplinary and multicultural perspectives. In particular, Global Governance welcomes articles challenging the conventional wisdom, whether written by scholars or by practitioners.

\section{0 \\ EDITORS}

Roger A. Coate, University of South Carolina Craig N. Murphy, Wellesley College

\section{$\infty$ \\ Edtorial Committee}

Hervé Cassan, United Nations

Jacques Fomerand, United Nations

University, $N A$

W. Andy Knight, Bishop's University

W. B. Ofuatey-Kodjoe, City University of New York

M.J. Peterson, UMASS, Amherst

Thomas G. Weiss, Brown University/ACUNS

\section{Vol. 1 No. 1 - WinTer 1995}

Democracy: A Newly Recognized Imperative Boutros Boutros-Ghali

Governance in the Twenty-First Century James N. Rosenau

Dealing with the Displaced: A Challenge to the International Community

Francis $M$. Deng

The New-Old Disorder in the Third World Mohammed Ayoob

The New United Nations Politics of Peace:

From Juridical Sovereignty to

Empirical Sovereignty

Michael Barnett

REVIEW EsSAY

Global Governance and Political Economy:

German and French Perspectives

Alfredo C. Robles, Jr.

$\sin$

\section{Vol. 1 No. 2 - MaY-Aug. 1995}

Compliancy with International

Environmental Norms

Harold K. Jacobson and Edith Brown Weiss

Reflecting on the Past and Contemplating the Future

Javiér Pérez de Cueller

The New Multilateralism and Nonproliferation:

Bring in Domestic Politics

Etel Solingen

Overcoming the Somalia Syndrome

Thomas $G$. Weiss

Implementation of Comprehensive Peace Agreements: Staying the Course in El Salvador

Alvaro de Soto and Graciana del Castillo

REviEw EssaY

Critical Reviews of Multilateral Evolution W. Andy Knight

Global Governance, a project of the ACUNS and the United Nations University, is published three times a year by Lynne Rienner Publishers (ISSN: 1075-2846). For further information about this and other Council programs, please contact: 


\section{CORNELL}

STUDIES IN

POLITICAL

\section{ECONOMY}

a series edited by

Peter J. Katzenstein

\section{Winners}

\section{and Losers}

How Sectors Shape

the Developmental

Prospects of States

D. MICHAEL SHAFER

What determines winners and losers in the international division of labor? In a book that reframes our thinking about success and failure in economic development,

Shafer proposes a new answer: sectoral analysis. $\$ 37.50$ cloth, $\$ 14.95$ paper

\section{The Political}

\section{Economy of Policy Coordination}

International Adjustment since 1945

MICHAEL C. WEBB

Webb explores how the growth of international markets affected the coordination of economic policy among nations. His analysis overturns the popular assumption that policy coordination has eroded as American hegemony has receded. $\$ 37.50$

\section{International}

\section{Governance}

Protecting the Environment in a Stateless Society

ORAN R. YOUNG

How can the global environment be safeguarded in the absence of a world government? Young draws on environmental issues to explore the nature of international governance. $\$ 32.50$ cloth, $\$ 13.95$ paper

\section{Enterprise} and the State in Korea

\section{and Taiwan}

\section{KARL J. FIELDS}

Fields explains the similarities and differences in the organization of big business in two of East Asia's powerful business groups and state bureaucracies. "A well-balanced analysis of an important aspect of industrial organization." -TUN-JEN CHENG, College of William and Mary. $\$ 35.00$

\section{Remaking the Italian Economy}

RICHARD M. LOCKE
"An innovative and persuasive
'micro-political' interpretation
that is destined to influence
how scholars assess and ex-
plain economic performance
in many communities well
beyond the borders of Italy."
- ROBERT D. PUTNAM,
Harvard University. \$29.95

International Organizations and Ethnic Conflict

\author{
EDITED BY \\ MILTON J. ESMAN \\ AND SHIBLEY TELHAMI
}

An overview of one of the most perplexing issues confronting the world today, this volume clarifies the changing role of international organizations in an increasingly fragmented world. "A timely and important study that significantly enhances our understanding of one of the most pressing international security challenges in the post-cold war era."

-JOHN GERARD RUGGIE, Columbia University $\$ 47.50$ cloth, $\$ 17.95$ paper

\section{Cooperation under Fire}

\section{Anglo-German Restraint \\ during World War II \\ JEFFREY W. LEGRO}

Legro here offers a new understanding of the dynamics of World War II and the sources of international cooperation. "An in-depth and scholarly analysis of this provocative and heretofore under-examined subject."-AMBASSADOR WILLIAM J. CROWE, JR. Cornell Studies in Security Affairs $\$ 35.00$

At bookstores, or call (607) 277-2211

(credit card orders only)

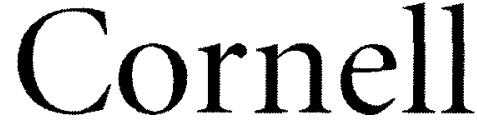




\section{Now Published by Blackwell!}

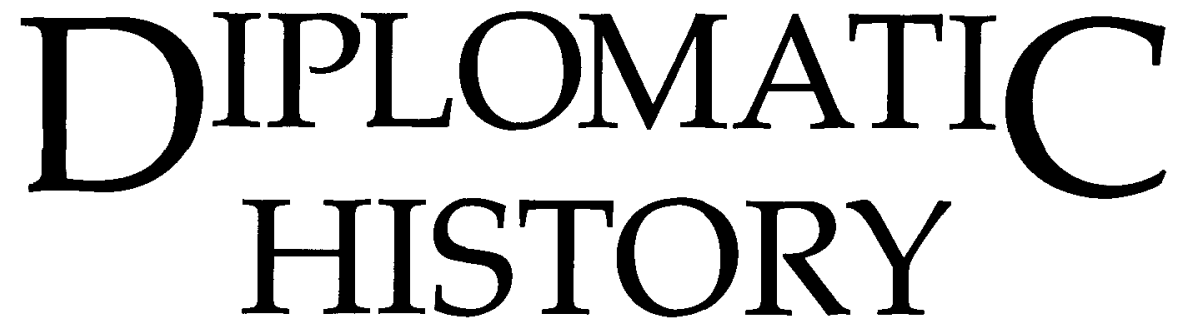

Edited by

MICHAEL HOGAN

The Ohio State University

Diplomatic History, the journal of record of the Society for Historians of American Foreign Relations, is the only journal devoted to US international history and foreign relations, broadly defined, including grand strategy, diplomacy, and issues involving gender, culture, ethnicity, and ideology. It examines US relations in a global and comparative context, and its broad focus appeals to a number of disciplines including political science, international economics, American history, national security studies, Latin American, Asian, African, and European studies.

Published in January, April, July, October ISSN 0145-2096

Prices for Volume 19

$$
\begin{array}{ll}
\text { Institutions: } & \$ 65.00(\mathrm{~N} . \text { America) } \\
& \$ 78.00 \text { (Rest of World) } \\
\text { Individuals: } & \text { NA }(N . \text { America) } \\
& \text { NA (Rest of World) }
\end{array}
$$

Journals Dept.,

Blackwell Publishers,

238 Main Street

Cambridge, MA 02142

E-Mail: blackwell.subscriptions@world.std.com

CALL TOLL-FREE
(800) 835-6770

$\mathbb{B}$

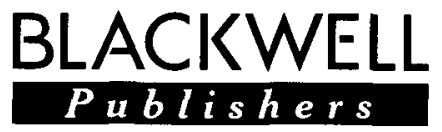




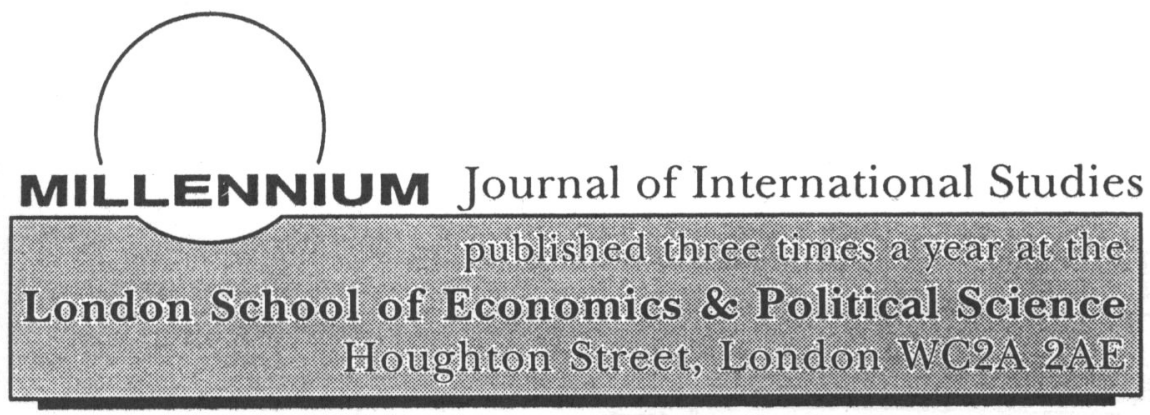

Recent articles include:

Philip G. Cerny Plurilateralism: Structural Differentiation and Functional Conflici in the Post Cold War World Order

Chris Brown Turtles all the Way Down: Anti-Foundationalism, Critical Theory and International Relations

Fred Halliday International Society as Homogeneity: Burke, Marx, and Fukuyama

Ole R. Holsti and The Structure of Foreign Policy Beliefs Among James N. Rosenau American Opinion Leaders - After the Cold War

Andrew Linklater The Question of the Next Stage in International Relations: A Critical-Theoretical Point of View

Christine Sylvester Empathetic Cooperation: A Feminist Method for IR

MILLENNIUM offers an extensive Book Reviews section in each issue and regular Discussion and Review sections.

Most Recent Special Issue:

Social Movements in World Politics (Vol.23, No.3)

Forthcoming Special Issue:

The Globalisation of Liberalism ( Vol 24, No.3)

Subscriptions:

Institutions $£ 45.00$ per annum (US $\$ 75.00$ : Canada $\$ 90.00$ )

Individuals $\quad £ 20.00 \quad$ (US $\$ 33.00$ : Canada $\$ 40.00$ )

Students $\quad £ 12.00 \quad$ (US $\$ 20.00$ : Canada $\$ 25.00$ )

Telephone: $+44(0) 1719557438 \quad$ Fax: $+44(0) 1719557446$ 
IO, INTERNATIONAL ORGANIZATION

\section{Low Frequancy}

Quarterly; Winter, Spring, Summer, Fall

\begin{tabular}{|l|l|l|l|l|l|l|l|l|}
\hline \multicolumn{7}{|c|}{ 2. Publication No. } \\
\hline 0 & 0 & 2 & 0 & - & 8 & 1 & 8 & 3 \\
\hline
\end{tabular}

MIT Press, 55 Hayward Street, Cambridge, Middiesex, ZA-4) (N21 Prizte(399

\section{Complete Meiling Address of Hendquarters or General Business Office of Publisher (Not Printer)}

same as 1tem 7

2. Full Names and Complete Mailing Addresses of Publisher, Editor, and Managing Eofitor (Do Nof Leave Elank) Publisher (Name and Complote Mailing Address)

MIT Press, 55 Hayward Street, Cambridge, MA 02142-1399

\section{Editor (Name and Complete Moiling Address)}

John S, Ode11, Center for International studies, Univ, of Southern California, Los Angeles, CA 90089-0035

Managing Editor (Name and Complete Maiting Address)

Candyce Xornblum Anger, Center for International Studies, Univ. of Southern California, Los Angeles, CA 90089-0035

10. Owner (If owned by a conporation, its name and address must be stated and also immediatefy thereafter the nemes and addrasses of stockhotders owning or hotding i percent or more of the total amount of stock. If not owned by a copporation, the names and addnesses of the individual owners must be given. If owned by a partmership or other unincoporaled fim, its name and adoress as well as that of ach individual musf of given. If the publication is published by a nonprofit omanization, its name and address must be stated) (Oo Not Leave Blenk.

\begin{tabular}{c|c}
\hline \multicolumn{1}{c|}{ Full Name } & \multicolumn{1}{c}{ Complete Mailing Addreas } \\
\hline MIT Presg & 55 Hayward Street, Cambridge, MA 02142-1399 \\
\hline & \\
\hline & \\
\hline
\end{tabular}

11. Known Bondholders, Mongageses, and Othet Security Holders Owning or Holding 1 Percent or More of Total Arnount of Bonds, Mortgages, or Other Securities. If none. check here. If None

\begin{tabular}{c|c}
\hline Full Name & Complete Mailling Addrass \\
\hline & \\
\hline & \\
\hline & \\
\hline
\end{tabular}

12. Foe completion by nonprofl creanizations authorized to mail at special rates. The purpose, function, and nonprofit status of this organization and the exernpt thes for lederal income tax purposes: (Check ono) G Has Nol Changed Ouning Preceoling 12 Months

C Has Changed Ouring Preceding 12 Months (II changed. publisher mest submit explasiation of change with this statament) 


\begin{tabular}{|c|c|c|}
\hline $\begin{array}{l}\text { 13. Pubication Name } \\
\text { 10, INTERNATIONAL ORGANIZATION }\end{array}$ & $\begin{array}{c}\text { 14. Iasue Oate for Circuladion Date Belk } \\
48: 3 \text {, Summer } 1994\end{array}$ & \\
\hline Extent and Nature of Circuiation & $\begin{array}{l}\text { Average No. Copies Each beswe } \\
\text { During Preceding } 12 \text { Month: }\end{array}$ & $\begin{array}{l}\text { Actual No. Copies of Single lasus } \\
\text { Publiahod Neareat to Filing Date }\end{array}$ \\
\hline 2. Total No. Copies (Not Press Aun) & 3936 & 4003 \\
\hline $\begin{array}{l}\text { b. Paid and/or Requasted Cireutation } \\
\text { (1) Sales Through Dealers and Cartiers. Streot Vendors, and Counter Sales } \\
\text { (Not Mailed) }\end{array}$ & 0 & 0 \\
\hline $\begin{array}{l}\text { (2) Paid or Aequested Mail Subsenptions } \\
\text { (inctude Advertisurs' Proof Copies/Exchange Copies) }\end{array}$ & 2952 & 3061 \\
\hline $\begin{array}{l}\text { 6. Total Paid andor Aequested Clireulation } \\
\text { (Sum of 15১(1) and } 15 b(2) \text { ) }\end{array}$ & 2952 & 3061 \\
\hline $\begin{array}{l}\text { 1. Frev Oistribution by Mail } \\
\text { (Stmples, Complimentary, and Other Free) }\end{array}$ & 57 & 57 \\
\hline - Free Distribution Outside the Mail (Carriers or Other Means) & 74 & 74 \\
\hline 1. Total Free Distribution (Sum of $15 d$ and $15 e$ ) & 131 & 131 \\
\hline 9. Total Distribution (Sum of $15 \mathrm{C}$ and 15 ) & 3083 & 3192 \\
\hline $\begin{array}{l}\text { h. Copies Not Distributed } \\
\text { (1) Otfice Use, Leftovers, Spoiled }\end{array}$ & 853 & 811 \\
\hline (2) Retum trom News Agents & 0 & 0 \\
\hline i. Total (Sum of 15g. 15h(1). and 15h(2)) & 3936 & 4003 \\
\hline $\begin{array}{l}\text { Percent Paid and/or Requested Circulation } \\
(15 c / 15 g \times 100)\end{array}$ & $96 \%$ & $96 \%$ \\
\hline
\end{tabular}

16. This Statement of Ownership will be printed in the issue of mis publication. B Check box it not required to publish.

\begin{tabular}{|c|c|c|}
\hline \multirow[t]{2}{*}{ 17. Signarure and Title of Editor. Publisher, Business Manager, or Owner } & \multicolumn{2}{|c|}{ Date } \\
\hline & , Circulation Manager & $10 / 1 / 94$ \\
\hline
\end{tabular}

t certily that all information turnished on this form is true and complete. I understand that anyone who fumishes false or misleading intormation on this form or who omits material or information requested on the form may be subject to criminal sanctions (including fines and imprisonment) and/or civil sanctions (inclueting mustiple damages and civil penalties).

\section{Instructions to Publishers}

1. Complete and fite one copy of this tom with your postmaster on or belore October 1 , annually. Keep a copy of the completed form for your records.

2. Inctude in itams 10 and $1 \mathrm{t}$, in cases where the stockholder or security holder is a trustee, the name of the person or corporation for whom the trustee is acting. Also include the names and addresses of individuals who are stockholders who own or hold $t$ percent or more of the lotal amount of bonds, mortgages, or other securities of the publishing corporation. In item 11 , if none, check box. Use blank sheets if more space is required.

3. Be sure to fumish all intormation called for in item 15, regarding circulation. Free circulation must be shown in items $15 d, e$, and $t$.

4. It the publication had second-class authorization as a general or requester publication. this Statement of Ownership, Management, and Circulation must be published; it must be printed in any issue in October or the first printed issue after October, if the publication is not published during October.

5. In item 18, indicate date of the issue in which this Statement of Ownership will be printed.

a. hem 17 mustbe signed.

Faliure to file or publlsh a statement of owmership may lead to suspension of second-class authorization. 


\section{DISCOVER WHAT THOUSANDS OF READERS ALREADY KNOW ABOUT THE WORLD \& I}

"One of the most extraordinary magazines in America." Dictionary of Literary Biography Yearbook

"... a treasurehouse of information..." The Daily Reflector, Greenville, N.C.

"I have canceled all my other magazine subscriptions... your magazine contains the best of them and better." D. Stuart Carr, Richmond, VA.

\section{THE COLLECTIBLE MONTHLY}

No other single publication provides the same in-depth, entertaining, and objective coverage of national and international events as THE WORLD \& I.

\section{THE BEST AND THE BRIGHTEST}

Each monthly issue contains over four hundred pages of the most thought-provoking analysis and informative features you'll find anywhere. Every issue presents over 50 articles by scholars and experts representing widely divergent schools of thought, all accompanied by hundreds of color photographs and thoughtfuol illustrations.

\section{ON THE CUTTING EDGE}

The diversity of topics covered makes THE WORLD \& I an important publication for professionals, parents, and students alike. In each issue you'll find penetrating analyses under the headings Current Issues, The Arts, Life, Natural Science, Culture, Book World, Life and Ideals, and Currents in Modern Thought.

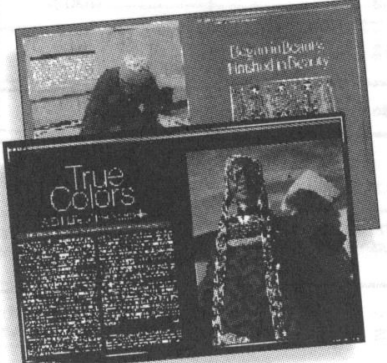

\section{AN EXCEPTIONAL VAUUE}

For those of you who enjoy learning, THE WORLD \& I provides many pleasurable hours of opening up your world to new cultures and ideas. An investment well worth the price, THE WORLD \& I is an important addition to any home where education is valued.

\section{ORDER YOUR RISK-FREE TRIAL ISSUE TODAY!}

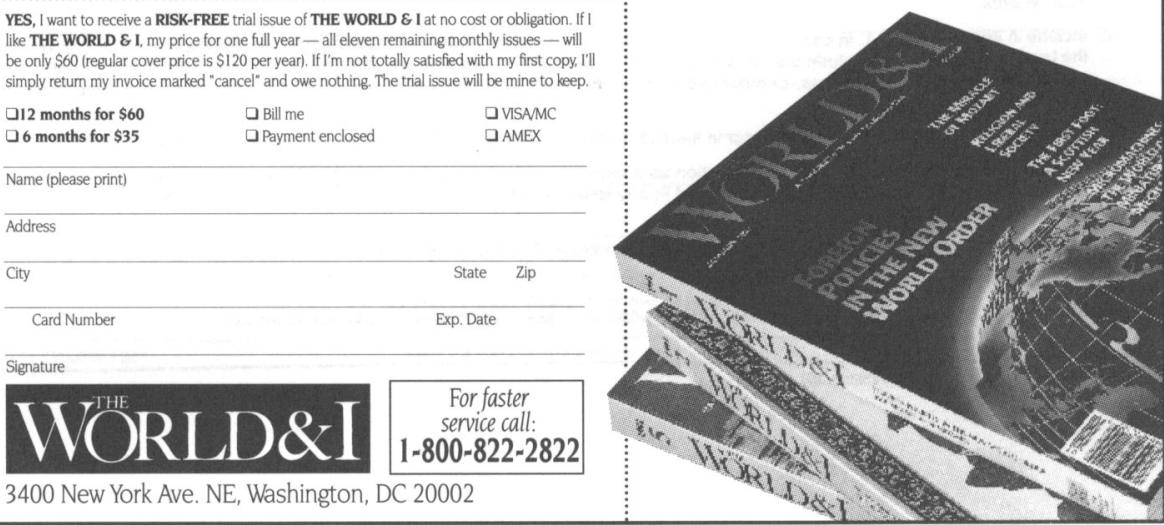




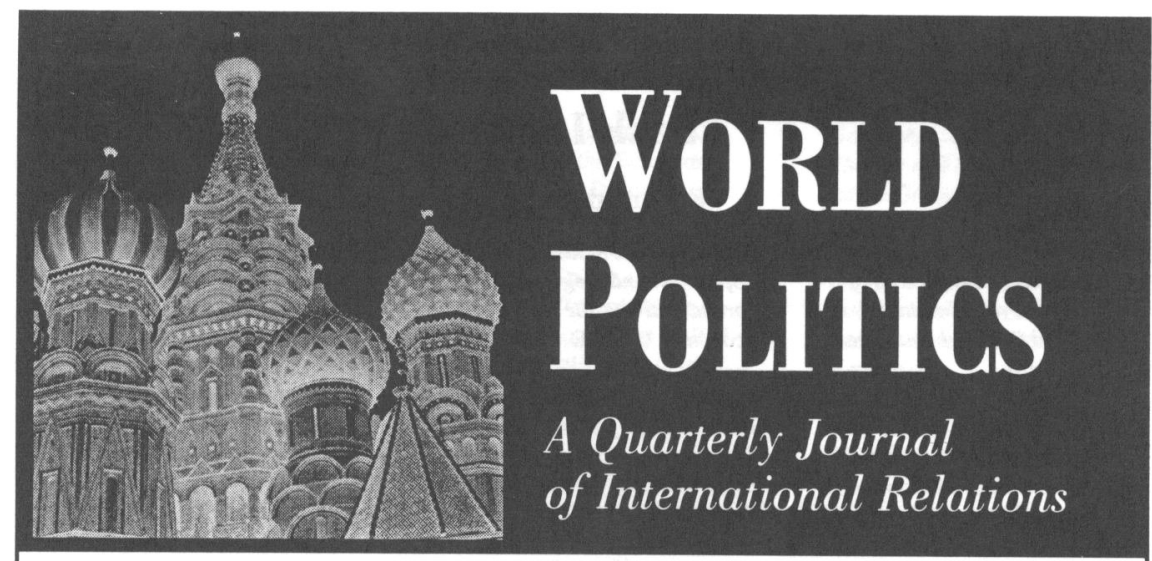

Prepayment is required. ANNUAL SUBSCRIPTIONS: $\$ 24.00$, individuals; $\$ 51.00$, institutions. FOREIGN POSTAGE:

$\$ 4.00$, Canada \& Mexico; $\$ 10.00$ outside North America. SINGLE-ISSUE PRICE:

$\$ 8.00$, individuals; $\$ 15.00$, institutions. Payment must be drawn on a U.S. bank in U.S. dollars or made by international money order. MD residents add $5 \%$ sales tax.

For orders shipped to Canada add 7\% GST (\#124004946).

SEND ORDERS TO:

The Johns Hopkins University Press, P.O. Box 19966,

Baltimore, MD 21211.

To place an order using Visa or MasterCard, call toll-free 1-800-548-1784, FAX us at (410) 516-6968, or send Visa/ MasterCard orders to this E-Mail address: jlorder@jhunix.hef.edu
JOHN WATERBURY, EDITOR

Princeton University

Since 1948, World Politics has published articles, research notes, and review articles representing all of the disciplines, methods, and viewpoints relevant to international relations and comparative politics. Political scientists and others turn to World Politics to stay on top of the latest theoretical developments in the field. World Politics was twice rated the \#1 refereed political science journal in two separate surveys conducted by PS. Published quarterly in October, January, April, and July under the editorial sponsorship of the Center of International Studies at Princeton University.

THE JANUARY 1995 (voL. 47, No. 2) ISSUE INCLUDES: Regionalization, Hierarchy, and the Industrialization of East Asia - State Power, Institutional Change, and the Politics of Privatization in Russia - T.H. Marshall in the Hands of Social Reformers 


\section{International $\mathrm{O}_{\text {rganization }}$ Back Issues}

Vol. 33, No. 1, Winter 1979

The Political Consequences of the Product Cycle; Industrial History and Political Outcomes James R. Kurth

Vol. 33, No. 3, Summer 1979 The Management of Surplus Capacity: Or How Does Theory Stand Up to Protectionism 1970s Style?

Susan Strange

Vol. 33, No. 4, Autumn 1979

An Economic Theory of Mutually Advamageous Issue Linkages in International Negotiations Robert D. Tollison, Thomas D. Willett

Vol. 34, No. 1, Winter 1980 Towards a Marxist Theory of European Integration Peter Cocks

Vol. 34, No. 2, Spring 1980 Self-Reliance in Theory and Practice in Tanzanian Trade Relations Thomas J. Biersteker

Vol. 35, No. 2, Spring 1981 Sphere of Flying: The Politics of International Aviation Christer Jönsson

Vol. 35, No. 3, Summer 1981 Third World Indebied Indus. trialization: International Finance and State Capitalism in Mexico, Brazil, Algeria, and South Korea Jeff Frieden

Vol. 35, No. 4, Autumn 1981 The GATT and the Regulation of Trade Barriers: Regime Dynamics and Functions Jock A. Fintayson, Mark W. Zacher

Vol. 36, No. 1, Winter 1982 The Political Economy of Indian Joint Industrial Ventures Abroad Dennis J. Encarnation

Vol, 36, No. 3, Summer 1982 Managing the Global Commons Per Magnus Wijkman

\section{Featured Articles}

Vol. 36, No. 4, Autumn 1982

Capitalism and Hegemony: Yorubaland and the International Economy David D. Laitin

Vol. 37, No. 4, Autumn 1983

The Unraveling of the Multi-Fiber Arrangement, 1981: An Examination of International Regime Change Vinod $\mathrm{K}$. Aggarwal

Vol. 38, No. 1, Winter 1984 Breaking with Orthodoxy: The Politics of Economic Policy Responses to the Depression of the 1930s Peter Alexis Gourevitch

Vol. 38, No. 2, Spring 1984 The Hegemon's Dilemma: Great Britain, the United States, and the International Economic Order Arthur A. Stein

Vol. 38, No. 3, Summer 1984 Policy Coordination by Major Western Powers in Bargaining with the Third World: Debt Relief and the Common Fund Barbara B. Crane

Vol. 38, No. 4, Autumn 1984

Economic Structure and International Security: The Limits of the Liberal Case Barry Buzan

Vol. 39, No. 1, Winter 1985

The Empire Strikes Back: The Transformation of the Eastern Bloc from a Soviet Asset to a Soviet Liability Valerie Bunce

Vol. 39, No. 4, Autumn 1985

The Limits of Hegemonic Stability

Theory Duncan Snidal

Vol. 40, No. 1, Winter 1986

Neomercantilism and International

Economic Stability Paolo

Guerrieri, Pier Carlo Padoan

Vol. 40, No. 3, Summer 1986

International Human Rights: $A$

Regime Analysis Jack Donnelly

What is Nationalism and Why

Should We Study It?

Ernst B. Haas
Vol. 41, No. L, Winter 1987

Crisis Prevention and the

Austrian State Treaty

Deborah Welch Larson

Vol. 41, No. 3, Summer 1987 Nordic Economic Policles in the 1970s and 1980s Lars Mjøset

Vol. 41, No. 4, Autumn 1987 Quasi-States, Dual Regimes, and Neoclassical Theory:

International Jurisprudence and the Third World Robert $\mathrm{H}$. Jackson

Vol. 42, No. 2, Spring 1988 NATO and the Persian Gulf: Examining Intra-alliance Behavior Charles A. Kupchan

Vol. 43, No. 1, Winter 1989 The Impact of Ideas on Trade Policy: The Origins of U.S. Agricultural and Manufacturing Policies Judith Goldstein

Vol. 44, No. 3, Summer 1990 Multilateral Negotiations: A Spatial Analysis of the ArabIsraeli Dispute Bruce Bueno de Mesquita

Vol. 44, No. 4, Autumn 1990 How Japan Affects the International System Henrik Schmiegelow and Michèle Schmiegelow

Vol. 45, No. 2, Spring 1991

The East European Countries and GATT: The Role of Realism, Mercantilism, and Regime Theory in Explaining East-West Trade Negotiations Leah Haus

Vol. 45, No. 3, Summer 1991 Political Leadership and Regime Formation: On the Development of Institutions in International Society Oran R. Young

Vol. 46, No. 1, Winter 1992 SPECIAL ISSUE: Knowledge, Power, and Internationl Policy Coordination Edited by Peter M. Hass 
Vol. 46, No. 3, Summer 1992 SYMPOSIUM: Multilaterallsm with John Gerard Ruggie, James A. Caporaso, Steve Weber, Miles Kahler

Vol, 46, No. 4, Autumn 1992

From Competition to Collaboration: The Challenge of

Commercial-Class Aircraft

Manufacturing Vicki L. Golich

Vol. 47, No. 1, Winter 1993

Domestic Reform and

International Change: The

Gorbachev Reforms in Historical

Perspective Valerie Bunce

Vol. 47, No. 2, Spring 1993

The International Labor

Organization and the Welfare

State: Institutional Effects on

National Welfare Spending.

1960-80 David Strang and

Patricia Mei Yin Chang
Vol. 47, No. 3, Summer 1993

Human Rights, Principled Issue-

Networks, and Sovereignty in Latin

America Kathryn Sikkink

Vol. 47, No. 4, Autumn 1993

Europeans and the European

Community: The Dynamics of

Public Support for European

Integration Richard C. Eichenberg

and Russell J. Dalton

International Organizations As

Teachers of Norms: The United

Nations Educational, Scientific.

and Cultural Organization and

Science Policy Mantha Finnemore

Vol. 48, No. 1, Winter 1994

Burden-sharing in the Persian Gulf

War Andrew Bennett. Joseph

Lepgold, and Danny Unger

The Interest-based Explanation of

International Environmental Policy

Detlef Spriz and Tapani Vaahtoranta
Vol. 48, No. 2, Spring 1994 SYMPOSIUM: The End of the

Cold War and Theories of

International Relations

Political Learning by Doing:

Gorbachev As Uncommitted

Thinker and Motivated Learner

Janice Gross Stein

Understanding Change in

International Politics: The Soviet

Empire's Demise and the

International System Rey

Koslowski and Friedrich V.

Kratochwil

Vol. 48, No. 3, Summer 1994

A Security Regime Among

Democracies: Cooperation

Among Iroquois Nations Neta

C. Crawford

The Origins and Sustainability of

Mexico's Free Trade Policy

Manuel Pastor and Carol Wise

Free Trade, Fair Trade, Strategic

Trade, and Protectionism in the

U.S. Congress, 1987-88 Stanley

D. Nollen and Dennis P. Quinn

\section{International $\mathbf{O}_{\text {rganization }}$}

Please send me the following back issue(s):

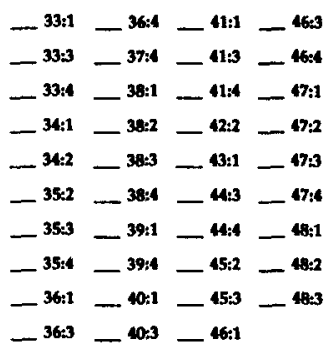

I am ordering

copy(coples) at:

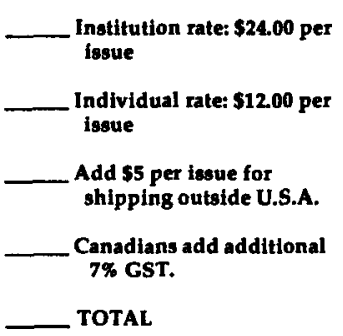

Prices subject to change without notice. Prepayment required. Send check or money order-drawn on a U.S. bank in U.S. funds, payable to International Organization-AMEX, MC, or VISA number to:

Circulation Department MIT PRESS JOURNALS 55 HAYWARD STREET CAMBRIDGE, MA 02142-1399 USA

TEL: (617) 253-2889

FAX: (617) 258-6779

journals-ordersomit.edu

Check or money order-drawn on a U.S. bank in U.S. funds, payable to Intemational Organization-is enclosed.

Charge to my _ AMEX _ MC _ VISA Account No.

Expiration Date Signature/Today's Date

Print cardholder's name

Send to (please print clearly):

Name

Company/Department

Address

Clty/State/Province/ZIP/Country

Daytime phone Gift from 


We are
proud to
announce
the launch
of a new journal
analyzing the

interaction

of the press,

politics,

and public

policymaking.
The Harvard International Journal of

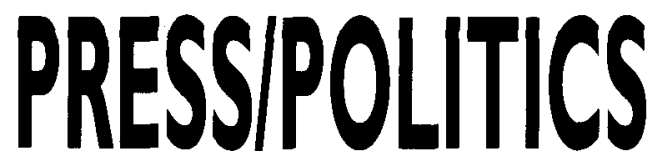

Marvin Kalb and Pippa Norris, Editors

The journal is published by The MIT Press in conjunction with the Joan Shorenstein Center on the Press, Politics and Public Policy at the Kennedy School of Government, Harvard University.

The first issue of Press/Politics will be published in February 1996, with four issues per year. The editors invite academics and journalists to forward submissions on topics reflecting a broad spectrum of intellectual disciplines and practitioner experiences.

Press/Politics welcomes articles on, among other topics:

- media production, contents and effects

- the role of television, radio and newspapers in campaigns and elections

- ethical issues in journalism

- comparative studies of media systems

- technological developments and global communications

- government regulation and freedom of the press

- diversity and the press

- the interaction between the media, politics, and public policy in cross-national perspective

The journal includes three types of contribution:

- articles original academic research subject to blind peer review (6,000-10,000 words)

- notes current events, topical issues, or new developments (1,000-3,000 words)

- current debate brief articles expressing stong views about a current controversy (2,000-3,000 words) (1) GST. Published quarterly by The MIT Press in. winter, spring, summer, and fall. ISSN 108I-I80X. Volume I은 forthcoming. 
INTENTIONAL OIL POLLUTION AT SEA

Environmental Policy and Treaty Compliance

Ronald B. Mitchell

Although an international treaty governs how tankers must dispose of oil, compliance has been a problem. Intentional Oil Pollution at Sea combines theoretical analysis with a rigorous empirical evaluation of changes in the compliance process over time and identifies policies that have increased compliance by governments and the oil transportation industry.

Global Environmental Accords series 260 pp., 6 illus. $\$ 34.95$

\section{POPULATION ECONOMICS}

Assaf Razin and Efraim Sadka From Malthus to Becker, the economic approach to population growth and its interactions with the surrounding economic environment has undergone a major transformation. Population Economics elucidates the theory behind this shift and the consequences for economic policy. 250 pp., 22 illus. $\quad \$ 30.00$ (January 1995)

\section{THE MIT ENCYCLOPEDIA OF THE JAPANESE ECONOMY}

Robert C. Hsu

From "Administrative guidance" (gyosei shido) to the "Zenshinren Bank," this encyclopedic dictionary defines basic concepts and terms from the lapanese economy.

460 pp. $\$ 45.00$
INTERNATIONAL ECONOMIC POLICY IN THE 1990S

William R. Cline

"This book is significant for a number of reasons. Cline integrates many of the concepts that form the basis of modern international economic policy formation and analysis into a coherent, accessible whole. The book is timely in that it focuses on important current international economic issues, yet timeless in its treatment of these issues. Cline's book will be valuable to scholars, policymakers, and businesspeople for years to come." - Michael Enright, Harvard University

300 pp., 31 illus. $\quad \$ 35.00$

(December)

\section{MANAGING THE GLOBAL COMMONS}

The Economics of Climate Change William D. Nordhaus

"No one is better than Bill Nordhaus at combining theory with real-world practicalities in addressing the important policy issues of the day. This book is no exception. Information and insights from a number of fields are woven together to produce another policy analysis masterpiece." - John P. Weyant, Stanford University 240 pp., 37 illus. $\$ 29.95$

\section{The MIT Press 55 Hayward Street Cambridge, MA 02142 \\ \& Fitzroy House, 11 Chenies St. London WC1E 7ET ENGLAND}

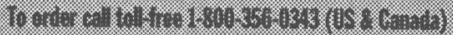
4. 671 .

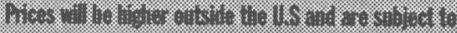

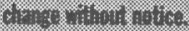




\section{Copies of articles from this publication are now available from the UMI Article Clearinghouse.}

For more information about the Clearinghouse, please fill out and mail back the coupon below.

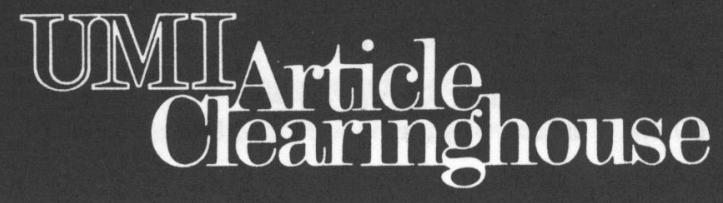

Yes! I would like to know more about UMI Article Clearinghouse.

I am interested in electronic ordering through the following system(s):

$\square$ DIALOG/Dialorder

$\square$ OnTyme

$\square$ ITT Dialcom

$\square$ OCLC ILL Subsystem

$\square$ Other (please specify)

$\square \mathrm{I}$ am interested in sending my order by mail.

$\square$ Please send me your current catalog and user instructions for the system(s) I checked above.

Name

Title

Institution/Company

Department

Address

City State Zip

Phone (_

Mail to: University Microfilms International

300 North Zeeb Road, Box 91 Ann Arbor, MI 48106 


\section{A Journal of \\ Political and \\ Economic Affairs}

\section{Supported by the World Peace Foundation}

Edited at the University of Southern California Published by The MIT Press 